\title{
Positive sparse coding of natural images: a theory for simple cell tuning
}

\author{
David GT Barrett ${ }^{1,2^{*}}$, Sophie Denève ${ }^{1}$, Christian K Machens ${ }^{2}$ \\ From Twenty Second Annual Computational Neuroscience Meeting: CNS*2013 \\ Paris, France. 13-18 July 2013
}

One of the most celebrated results in neuroscience is the observation that simple cells in the visual cortex are tuned to the orientation and polarity of edges in visual stimuli [1]. While orientation tuning has been the subject of intense investigation, the polarity tuning of cells is poorly understood; a simple cell responds either to a bright edge with dark flanks, or to the opposite polarity, a dark edge with bright flanks. We ask, what is the function of this polarity tuning, if any, and how does it arise from the underlying neural circuitry?

Perhaps the most influential functional theory of simple cell tuning is sparse coding [2]. According to this theory, the function of simple cells is to represent natural images sparsely (using as few active neurons as possible). This representation is desirable because it is metabolically and computational efficient. It explains orientation tuning because sparse coding neurons are tuned to edge-like stimuli at different orientations. However, there are two problems with this 'classical' sparse coding (Table 1). First of all, it predicts that every cell is tuned to both polarities, whereas simple cells only respond to a single polarity. Secondly, it requires neurons to represent images using negative firing rate
Table 1 Tuning properties

\begin{tabular}{cccc}
\hline & $\begin{array}{c}\text { Classical sparse } \\
\text { coding }\end{array}$ & $\begin{array}{c}\text { Positive } \\
\text { sparse } \\
\text { coding }\end{array}$ & $\begin{array}{c}\text { Simple } \\
\text { cells }\end{array}$ \\
\hline $\begin{array}{c}\text { Orientation } \\
\text { tuning }\end{array}$ & $\checkmark$ & $\checkmark$ & $\checkmark$ \\
Position tuning & $\checkmark$ & $\checkmark$ & $\checkmark$ \\
Polarity tuning & $x$ & $\checkmark$ & $\checkmark$ \\
Positive firing & $x$ & $\checkmark$ & $\checkmark$ \\
\hline
\end{tabular}

values, which is clearly impossible for a spiking neural network.

We solve both of these problems, simultaneously, by proposing that simple cells provide a positive sparse coding of natural images. This is similar to 'classical' sparse coding but with positive firing rates alone. We find that positive sparse coding neurons have both orientation tuning and polarity tuning (Figure 1, Table 1). Orientation tuning emerges because natural images typically contain edges at many different orientations, and a sparse code will capture these natural statistics. Polarity tuning emerges as a natural consequence of the positivity constraint because a neuron with positive

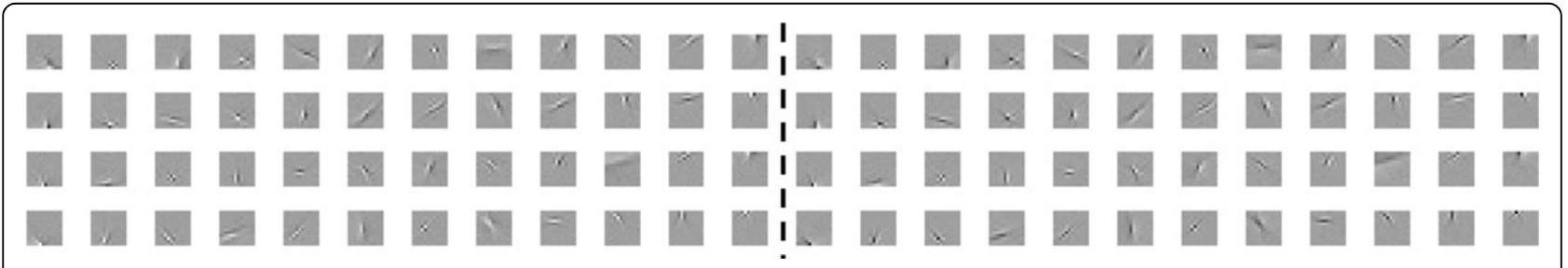

Figure 1 Positive sparse coding filters of natural images. Each image is the sparse coding filter for a single neuron. These are tuned to orientation and polarity (left side neurons tuned to the opposite polarity of right side neurons).

\footnotetext{
* Correspondence: david.barrett@ens.fr

'Institut D'Étude de la Cognition, École Normale Supérieure, Paris, France

Full list of author information is available at the end of the article
}

\section{Ciomed Central}

(c) 2013 Barrett et al; licensee BioMed Central Ltd. This is an Open Access article distributed under the terms of the Creative Commons Attribution License (http://creativecommons.org/licenses/by/2.0), which permits unrestricted use, distribution, and reproduction in any medium, provided the original work is properly cited. 
firing rates cannot represent edges with both polarities on its own.

This functional theory leads naturally to a spiking neural network implementation for simple cells, because spiking network models necessarily have positive firing rates. We find that a network of tightly balanced leaky integrate-and-fire neurons can produce spike trains that optimise our positive sparse coding cost function. In this way, we can marry spiking constraints with neural function to understand the orientation and polarity tuning of simple cells.

\section{Author details}

${ }^{1}$ Institut D'Étude de la Cognition, École Normale Supérieure, Paris, France.

${ }^{2}$ Champalimaud Centre for the Unknown, Lisbon, Portugal.

Published: 8 July 2013

\section{References}

1. Hubel DH, Wiesel TN: Receptive fields binocular interaction and functional architecture in the cat's visual cortex. J Physiol 1962, 160:106-154.

2. Olshausen BA, Field DJ: Emergence of Simple-Cell Receptive Field Properties by Learning a Sparse Code for Natural Images. Nature 1996, 381:607-609.

doi:10.1186/1471-2202-14-S1-P250

Cite this article as: Barrett et al:: Positive sparse coding of natural images: a theory for simple cell tuning. BMC Neuroscience 2013 14(Suppl 1):P250.
Submit your next manuscript to BioMed Central and take full advantage of:

- Convenient online submission

- Thorough peer review

- No space constraints or color figure charges

- Immediate publication on acceptance

- Inclusion in PubMed, CAS, Scopus and Google Scholar

- Research which is freely available for redistribution

Submit your manuscript at www.biomedcentral.com/submit 